\title{
PENERAPAN BIAYA KUALITAS UNTUK MENINGKATKAN EFISIENSI BIAYA PRODUKSI PADA CV. ULUNG BAURENO
}

\author{
Nurrofiah $^{1}$, Yahya $^{2}$, Hartono $^{3}$ \\ ${ }^{1}$ Fakultas Ekonomi, Universitas Islam Darul ‘Ulum Lamongan \\ ${ }^{2}$ STIESIA Surabaya \\ ${ }^{3}$ Fakultas Ekonomi Universitas Islam Majapahit \\ Email ${ }^{3}$ : hartono.eka@gmail.com
}

\begin{abstract}
Abstrak
Dalam era globalisasi ekonomi dunia saat ini manajemen perusahaan saling berkompetisi. Kualitas merupakan salah satu faktor utama yang harus diperhatikan oleh perusahaan agar tetap dapat bertahan di tengah persaingan yang kompetitif. Obyek dalamPenelitian ini perusahaan rokok yaitu CV. Ulung Baureno Bojonegoro. Variabel dalam penelitian ini adalah biaya kualitas sebagai variabel independen $(\mathrm{X})$ dan efisiensi biaya produksi sebagai variabel dependen (Y). Pendekatan penelitian yang digunakan adalah pendekatan eksplanatory research dan metode yang digunakan adalah metode deskriptif kuantitatif. Hasil penelitian total biaya kualitas pada tahun 2018 yang diakui oleh perusahaan adalah sebesar Rp 408.367.000 dengan persentase sebesar 3,96\%. Dari hasil taksiran yang diperoleh dengan menurunkan biaya pada kategori biaya pencegahan, biaya kualitas menurun sebesar Rp 233.117.000 atau sebesar 2,26\% dari total penjualan aktualnya. Sehingga dapat disimpulkan bahwa dengan menerapkan biaya kualitas dapat meningkatkan efisiensi biaya produksi.
\end{abstract}

\section{Kata kunci : Biaya Kualitas, Efisiensi, Biaya Produksi.}

\section{Abstrack}

In the current era of globalization of the world economy, company management competes with each other. Quality is one of the main factors that must be considered by companies so that they can survive in the midst of competitive competition. The author conducted this research in a cigarette company, CV. Ulung Baureno Bojonegoro. The variables in this study are quality costs as independent variables $(X)$ and production cost efficiency as the dependent variable $(Y)$. The research approach used is an explanatory research approach and the method used by the author is a quantitative descriptive method. The results of the research on total quality costs in 2018 recognized by the company amounted to Rp. 408.367 .000 with a percentage of $3.96 \%$. From the results of estimates obtained by lowering costs in the category of prevention costs, quality costs decreased by $R p 233.117 .000$ or equal to $2.26 \%$ of the actual sales total. So that it can be concluded that by applying quality costs can increase the efficiency of production costs.

Keywords: Quality Costs, Efficiency, Production Costs. 


\section{PENDAHULUAN}

Dalam era globalisasi ekonomi dunia saat ini manajemen perusahaan saling berkompetisi. Kompetisi yang semakin ketat ini secara langsung memberikan tekanan kepada perusahaan untuk meningkatkan kualitas produknya baik itu barang maupun jasa dalam upaya meningkatkan kepuasan pelanggan. Keberhasilan suatu perusahaan tidak dapat dicapai begitu saja tanpa adanya usaha yang maksimal dari usaha perusahaan yang bersangkutan.

Kualitas merupakan salah satu faktor utama yang harus diperhatikan oleh perusahaan agar tetap dapat bertahan di tengah persaingan yang kompetitif. Dengan meningkatkan kualitas secara berkesinambungan diharapkan akan mengurangi biaya karena terjadi pemborosan akibat rendahnya kualitas, pengerjaan ulang suatu produk karena ketidaksesuaian dengan standar dan biaya lain-lain, sehingga akan dapat meningkatkan keuntungan dari penjualan dan mengurangi biaya.

Dalam meningkatkan kualitas tersebut selalu dibutuhkan biaya, yang disebut dengan biaya kualitas. Menurut Krismiaji dan Aryani (2011:390) dalam Bawon, dkk. (2013) menyatakan bahwa biaya kualitas adalah biaya yang terjadi karena kualitas produk yang dihasilkan rendah. Biaya kualitas terdiri atas biaya pencegahan, biaya penilaian, biaya kegagalan internal dan biaya kegagalan eksternal.

Biaya kualitas merupakan bagian dari produksi, sehingga kenaikan atau penurunan biaya kualitas selalu mempengaruhi naik atau turunnya biaya produksi yang harus dikeluarkan. Salah satu fungsi mengapa biaya kualitas harus dihitung agar perusahaan dapat mengontrol biaya kualitas dan jumlah produk cacat yang dihasilkan oleh perusahaan sehingga tidak berdampak pada biaya produksi. Selain itu, biaya kualitas juga mempunyai fungsi untuk mengetahui apakah perusahaan sudah berjalan dengan baik atau tidak.

CV. Ulung Baureno Bojonegoro adalah perusahaan yang bergerak dibidang produksi rokok. Bahan baku utama yang digunakan dalam proses produksi adalah tembakau. Aktivitas penting pada perusahaan manufaktur adalah aktivitas mengubah bahan baku (material) menjadi produk jadi (finished goods) dengan tenaga kerja dan fasilitas produksi. Agar dapat bersaing, perusahaan sangat membutuhkan proses produksi yang efektif dan efisien, yang dapat dicapai dengan perencanaan dan pengendalian kualitas produk yang optimal.

\section{KAJIAN PUSTAKA}

\section{Akuntansi Biaya}

Menurut Horngren, dkk. (2008:3) dalam Tulende dan Ilat (2014) menyatakan akuntansi biaya menyediakan informasi yang dibutuhkan untuk akuntansi manajemen dan akuntansi keuangan. Akuntansi biaya mengukur dan melaporkan setiap informasi keuangan dan non keuangan yang terkait dengan biaya perolehan atau pemanfaatan sumber daya dalam suatu organisasi.

\section{Biaya}

Akuntan telah mendefinisikan biaya sebagai "suatu nilai tukar, pengeluaran, atau pengorbanan yang dilakukan untuk menjamin perolehan manfaat. Dalam 
akuntansi keuangan, pengeluaran atau pengorbanan pada tanggal akuisisi dicerminkan oleh penyusutan atas kas atau aset lain yang terjadi pada saat ini atau dimasa yang akan datang" (Carter 2009:30).

\section{Kualitas}

Prawirosentono (2007: 5) dalam Wahyuningtyas (2013) menyatakan bahwa kualitas adalah quality is fitness for use yang bila diterjemahkan secara bebas berarti, kualitas (mutu produk) berkaitan dengan enaknya barang tersebut digunakan. Artinya, bila suatu barang secara layak dan baik digunakan berarti barang tersebut bermutu baik.

\section{Biaya Kualitas}

Menurut Krismiaji dan Aryani (2011:390) dalam Bawon, dkk. (2013) menyatakan bahwa biaya kualitas adalah biaya yang terjadi karena kualitas produk yang dihasilkan rendah. Dengan demikian biaya kualitas berhubungan dengan identifikasi, reparasi dan pencegahan terjadinya produk yang tidak sempurna.

\section{Jenis-jenis Biaya Kualitas}

Menurut Carter (2009:218-219) Biaya kualitas dapat dikelompokkan ke dalam tiga klasifikasi besar yaitu biaya pencegahan (prevention cost), biaya penilaian (appraisal cost), dan biaya kegagalan (failure cost).

1. Biaya pencegahan (prevention cost) adalah biaya yang terjadi untuk mencegah terjadinya kegagalan produk. Biaya pencegahan adalah biaya yang dikeluarkan untuk mendesain produk dan sistem produksi berkualitas tinggi, termasuk biaya untuk menerapkan dan memelihara sistem-sistem tersebut. Pencegahan kegagalan produk dimulai dengan mendesain kualitas ke dalam produk dan proses produksi. Komponen-komponen dan peralatan berkualitas tinggi harus digunakan. Pemeliharaan preventif harus dilakukan secara berkala atas peralatan dan mesin untuk mempertahankan kualitas yang tinggi. Karyawan harus dilatih dengan baik dan bermotivasi tinggi. Seluruh karyawan, mulai dari manajemen puncak sampai setiap pekerja di pabrik harus terus-menerus mencari cara untuk memperbaiki kualitas produk.

2. Biaya penilaian (appraisal cost) adalah biaya yang terjadi untuk mendeteksi kegagalan produk. Biaya penilaian terdiri atas biaya inspeksi dan pengujian bahan baku, biaya inspeksi produk selama dan setelah proses produksi, serta biaya untuk memperoleh informasi dari pelanggan mengenai kepuasan mereka atas produk tersebut.

3. Biaya kegagalan (failure cost) adalah biaya yang terjadi ketika suatu produk gagal. Kegagalan tersebut dapat terjadi secara internal maupun ekstrenal.

a. Biaya kegagalan internal (internal failure cost) adalah biaya yang terjadi selama proses produksi, seperti biaya sisa bahan baku, biaya barang cacat, biaya pengerjaan kembali, dan terhentinya produksi karena kerusakan mesin atau kehabisan bahan baku.

b. Biaya kegagalan eksternal (external failure cost) adalah biaya yang terjadi setelah produk dijual, meliputi biaya untuk memperbaiki dan mengganti 
produk yang rusak selama masa garansi, biaya untuk menangani keluhan pelanggan, dan biaya hilangnya penjualan akibat ketidakpuasan pelanggan.

\section{Persentase Biaya Kualitas}

Peneliti akan menghitung persentase untuk masing-masing item biaya kualitas terhadap total penjualan. Menurut para pakar kualitas, program pengelolaan kualitas dengan baik oleh suatu perusahaan dimana biaya kualitasnya tidak lebih dari 2,5\% dari penjualan. Tujuannya adalah mempermudah untuk menilai signifikasi keuangan dari biaya kualitas dengan mengungkapkan biaya ini sebagai persentase dari penjualan aktual. Berikut ini rumus untuk mengetahui persentase tiap item biaya kualitas terhadap total produksi :

Persentase Biaya Kualitas $=\frac{\text { Biaya Kualitas }}{\text { Total Penjualan }} \times 100 \%$

Keterangan :

a. Persentase biaya kualitas = Hasil pembagian biaya kualitas dibagi dengan total penjualan dikali $100 \%$.

b. Biaya kualitas = Item biaya kualitas tiap periode.

c. Total penjualan $=$ Total penjualan tiap periode .

\section{Efisiensi}

Menurut Fahmi (2012:83) dalam Tulende dan Ilat (2014) menyebutkan efisiensi adalah pengukuran kinerja yang melihat dari segi pengerjaan sesuai dengan waktu (time) yang direncanakan, bahkan akan lebih baik jika bisa dilakukan penghematan secara lebih intensif.

\section{Biaya Produksi}

Menurut Rahmi, dkk. (2015) biaya produksi merupakan biaya-biaya yang terjadi untuk mengolah bahan baku menjadi produk jadi yang siap untuk dijual. Sedangkan menurut Bawon, et.,al. (2013) biaya produksi merupakan biaya yang berkaitan dengan pembuatan barang dan penyedia jasa.

\section{Unsur-unsur Biaya Produksi}

Unsur-unsur biaya produksi menurut Hansen dan Mowen (2009:42) dalam Bawon dkk. (2013), dapat diklasifikasikan dalam tiga jenis yaitu :

1. Biaya Bahan Baku Langsung

Bahan baku merupakan dasar yang akan digunakan untuk membentuk bagian yang menyeluruh menjadi produk jadi. Bahan baku yang digunakan untuk memproduksi dapat diperoleh melalui pembelian lokal, impor atau dari pengolahan sendiri. Biaya bahan baku meliputi harga pokok semua bahan yang dapat diidentifikasi dengan pembuatan suatu jenis produk, dengan mudah dapat ditelusuri atau dilihat perwujudannya di dalam produk selesai. Biaya bahan baku memiliki bagian yang signifikan dari total biaya suatu produk.

2. Biaya Tenaga Kerja Langsung

Tenaga kerja merupakan kegiatan fisik yang dilakukan oleh karyawan untuk mengolah suatu produk. Biaya tenaga kerja langsung meliputi biayabiaya yang berkaitan dengan penghargaan dalam bentuk upah yang diberikan 
kepada semua tenaga kerja yang secara langsung ikut serta dalam pengerjaan produk yang hasilnya kerjanya dapat ditelusuri secara langsung pada produk dan upah yang diberikan merupakan bagian yang besar dalam memproduksi produk.

3. Biaya Overhead Pabrik

Pada umumnya dalam suatu perusahaan biaya bahan baku dan biaya tenaga kerja langsung merupakan biaya produksi langsung. Semua biaya selain biaya bahan baku dan biaya tenaga kerja langsung yang berhubungan dengan produksi adalah biaya produksi tidak langsung. Istilah ini sesuai dengan sifat biaya overhead yang tidak dapat atau sulit untuk ditelusuri secara langsung kepada produk atau aktivitas-aktivitas pekerjaan. Biaya tidak langsung ini terkumpul dalam suatu kategori yang disebut biaya overhead pabrik (BOP) dan membutuhkan suatu proses alokasi yang adil untuk tujuan perhitungan harga pokok produksi atau jasa.

\section{Hubungan Biaya Kualitas dengan Efisiensi Biaya Produksi}

Biaya yang dikeluarkan untuk mengerjakan kembali produk yang gagal yang disebabkan karena pengendalian kualitas dari produk yang tidak baik atau yang tidak sesuai dengan spesifikasi standar kualitas yang telah ditetapkan, akan lebih besar dari pada biaya yang dikeluarkan untuk mencegah kegagalan produk tersebut terjadi. Oleh karena itu, jika kegiatan pengendalian kualitas dapat berjalan dengan baik, tanpa menghasilkan produk cacat dalam proses produksi. Maka pengulangan kerja akan berkurang karena menurunnya unit produk cacat. Hansen Mowen (2009:31) mengatakan bahwa: "Dengan menurunnya unit produk cacat maka sedikit tenaga kerja dan bahan yang digunakan untuk menghasilkan output yang sama. Penurunan jumlah unit cacat memperbaiki kualitas, sementara pengurangan jumlah input yang digunakan meningkatkan efisiensi produksi". Dengan adanya penurunan biaya kualitas maka efisiensi produksi meningkat maupun sebalikya apabila biaya kualitas menurun maka efisiensi produksi menurun (Bawon, et.,al. 2013).

\section{Kerangka Konseptual}

Gambar 1. Kerangka Konseptual

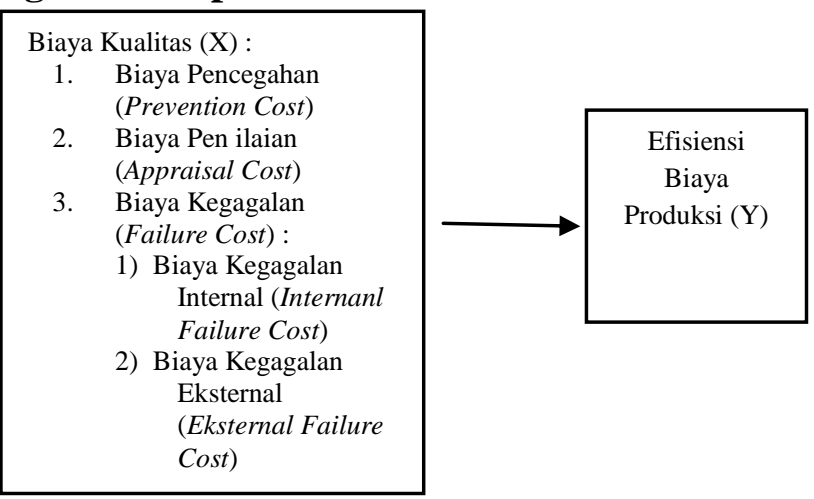

Bisman (Bisnis dan Manajemen): The Journal Of Business and Management 
Dalam penelitian ini terdapat dua variabel yaitu: biaya kualitas sebagai variabel independen $(\mathrm{X})$ dan efisiensi biaya produksi sebagai variabel dependen (Y).

\section{METODOLOGI PENELITIAN}

\section{Pendekatan Penelitian}

Pendekatan penelitian yang digunakan adalah pendekatan eksplanatori (exsplanatory research). Menurut Umar penelitian eksplanatori (exsplanatory research) adalah penelitian yang bertujuan untuk menganalisis hubunganhubungan antara satu variabel dengan variabel lainnya atau bagaimana suatu variabel mempengaruhi variabel lainnya (Ibrahim, dkk. 2018:48).

Sedangkan metode yang dipakai oleh penulis adalah metode deskriptif kuantitatif dimana peneliti hanya melakukan analisis yang bersifat menjelaskan (to explain) fenomena yang ada dihubungkan dengan teori yang mendasari riset yang dilakukan. Teknik analisis yang dilakukan sesuai dengan kebutuhan untuk menjawab pertanyaan riset (Chandrarin, 2017:134).

Peneliti melakukan penelitian ini di sebuah perusahaan rokok yaitu CV. Ulung Baureno Bojonegoro. Perusahaan ini berlokasi di Jl. Raya No. 139 Desa Gunungsari Kecamatan Baureno Kabupaten Bojonegoro. Waktu penelitian ini yaitu di mulai pada bulan Maret 2019 sampai selesai.Obyek penelitian yang akan dianalisis dalam penelitian ini adalah CV. Ulung Baureno Bojonegoro. Adapun yang menjadi subyek dalam penelitian ini adalah laporan biaya produksi pada tahun $2014-2018$.

\section{Teknik Pengambilan Sampel}

Pengambilan sampel dalam penelitian ini dilakukan dengan menggunakan teknik sampel bertujuan (purposive sampling). Menurut Arikunto (2014:183) teknik ini dilakukan secara langsung atau sengaja oleh peneliti dengan cara mengambil subjek bukan didasarkan atas strata, random atau daerah tetapi didasarkan atas adanya tujuan tertentu dengan pertimbangan bahwa sumber informasi (key information) memiliki pengetahuan yang diperlukan untuk memperoleh data-data penelitian seperti laporan biaya produksi pada tahun $2014-$ 2018.

\section{Jenis Data}

Data yang digunakan dalam penelitian ini adalah:

1. Data Primer, adalah data dalam bentuk verbal atau kata-kata yang diucapkan secara lisan, gerak-gerik atau perilaku yang dilakukan oleh subjek yang dapat dipercaya, dalam hal ini adalah subjek penelitian (informan) yang berkenaan dengan variabel yang diteliti (Arikunto, 2014:22). Data atau informasi yang dikumpulkan peneliti langsung dari sumbernya $\mathrm{CV}$. Ulung Baureno Bojonegoro. Dalam hal ini peneliti bertindak sebagai pengumpul data melalui observasi, wawancara dan dokumentasi.

2. Data sekunder, adalah data yang diperoleh dari dokumen-dokumen grafis (tabel, catatan, notulen rapat, SMS, dan lain-lain), foto-foto, film, rekaman 
video, benda-benda dan lain-lain yang dapat memperkaya data primer (Arikunto, 2014:22). Data yang diperoleh yakni sejarah perusahaan, struktur organisasi, dan data laporan biaya produksi.

\section{Variabel Penelitian}

Menurut Arikunto (2014:161) variabel adalah obyek penelitian, atau apa yang menjadi titik perhatian suatu penelitian. Dalam penelitian ini penulis melakukan pengukuran terhadap keberadaan suatu variabel dengan menggunakan instrumen penelitian. Setelah itu, penulis akan melanjutkan analisis untuk mencari pengaruh suatu variabel terhadap variabel lain. Berdasarkan hubungan antara satu variabel dengan variabel lain, maka variabel dalam penelitian ini adalah :

1. Variabel Independen

Variabel independen merupakan variabel yang diduga berpengaruh terhadap variabel dependen. Variabel independen dikenal juga sebagai variabel pemrediksi (predictor variable) atau disebut juga dengan istilah variabel bebas (Chandrarin, 2017:83). Dalam penelitian ini yang menjadi variabel independen adalah biaya kualitas (X).

\section{Variabel Dependen}

Variabel dependen merupakan variabel yang dipengaruhi atau yang menjadi akibat karena adanya variabel independen. Variabel dikenal juga sebagai variabel standar atau patokan (criterion variable) atau disebut juga dengan istilah variabel terikat (Chandrarin, 2017:83). Dalam penelitian ini yang menjadi variabel dependen adalah efisiensi biaya produksi (Y).

\section{Teknik Pengumpulan Data}

Teknik pengambilan data yang digunakan peneliti adalah :

1. Penelitian Lapangan (Field Research), yaitu penelitian yang dilakukan secara langsung, berupa :

a. Observasi, dilakukan untuk mengamati dan mengawasi sendiri obyek yang akan di teliti sehingga peneliti dapat mengetahui secara langsung kondisi perusahaan yang dijadikan sebagai objek penelitian.

b. Wawancara, yaitu teknik pengumpulan data dengan melakukan tanya jawab langsung kepada pihak-pihak yang terkait dengan masalah yang diteliti.

c. Dokumentasi yaitu teknik yang dilakukan dengan cara mengumpulkan data melalui dokumen-dokumen perusahaan mengenai data yang diperlukan.

2. Penelitian Perpustakaan (Library Reseach), yaitu penelitian yang dilakukan guna memperoleh pengetahuan dan landasan teori dari berbagai literatur, referensi dan hasil penelitian yang berhubungan dengan objek penelitian.

\section{Definisi Operasional}

Dalam penelitian ini yang menjadi variabel independen adalah biaya kualitas (X) dan yang menjadi variabel dependen adalah efisiensi biaya produksi (Y).

1. Pengertian Biaya Kualitas

Menurut Krismiaji dan Aryani (2011:390) dalam Bawon, dkk. (2013) menyatakan bahwa biaya kualitas adalah biaya yang terjadi karena kualitas produk yang dihasilkan rendah. Dengan demikian biaya kualitas berhubungan 
dengan identifikasi, reparasi dan pencegahan terjadinya produk yang tidak sempurna.

\section{Pengertian Efisiensi}

Menurut Fahmi (2012:83) dalam Tulende dan Ilat (2014) menyebutkan efisiensi adalah pengukuran kinerja yang melihat dari segi pengerjaan sesuai dengan waktu (time) yang direncanakan, bahkan akan lebih baik jika bisa dilakukan penghematan secara lebih intensif.

3. Pengertian Biaya Produksi

Menurut Rahmi, dkk. (2015) biaya produksi merupakan biaya-biaya yang terjadi untuk mengolah bahan baku menjadi produk jadi yang siap untuk dijual.

\section{Metode Analisis Data}

Untuk menyelesaikan permasalahan yang telah di uraikan, maka metode analisis yang digunakan oleh peneliti yaitu metode deskriptif kuantitatif. Yaitu metode mendeskripsikan, mengumpulkan, menyusun, dan menganalisis data untuk pemecahan masalah yang dihadapi.

\section{HASIL PENELITIAN DAN PEMBAHASAN}

\section{Hasil Penelitian}

Biaya kualitas dapat dikelompokkan ke dalam tiga klasifikasi besar yaitu biaya pencegahan (prevention cost), biaya penilaian (appraisal cost), dan biaya kegagalan (failure cost).

1. Biaya pencegahan (prevention cost) adalah biaya yang terjadi untuk mencegah terjadinya kegagalan produk. Yang termasuk biaya pencegahan adalah biaya pemeliharaan mesin dan peralatan.

2. Biaya penilaian (appraisal cost) adalah biaya yang terjadi untuk mendeteksi kegagalan produk. Yang termasuk biaya penilaian adalah biaya tenaga kerja pengawas/mandor. Di CV. Ulung Baureno Bojonegoro untuk pelaporan biaya tenaga kerja pengawas/mandor dijadikan satu dengan akun gaji karyawan tetap namun sudah ada pembagiannya tersendiri.

3. Biaya kegagalan (failure cost) adalah biaya yang terjadi ketika suatu produk gagal. Kegagalan tersebut dapat terjadi secara internal maupun eksternal.

a. Biaya kegagalan internal (internal failure cost) adalah biaya yang terjadi selama proses produksi.

b. Biaya kegagalan eksternal (external failure cost) adalah biaya yang terjadi setelah produk dijual.

Dalam CV. Ulung Baureno Bojonegoro tidak terdapat biaya kegagalan tersebut baik kegagalan internal maupun kegagalan eksternal. 
Tabel 1. Perincian Biaya Kualitas CV. Ulung Baureno Bojonegoro Tahun 2014-2018

\begin{tabular}{|c|c|c|c|c|c|}
\hline Item & 2014 & 2015 & 2016 & 2017 & 2018 \\
\hline \multicolumn{6}{|l|}{$\begin{array}{l}\text { Biaya } \\
\text { Pencegahan } \\
\text { : }\end{array}$} \\
\hline $\begin{array}{l}\text { Biaya } \\
\text { Pemeliharaa } \\
\text { n }\end{array}$ & Rp300.000.000 & Rp325.500.000 & $\begin{array}{l}\text { Rp347.977.00 } \\
0\end{array}$ & $\begin{array}{l}\text { Rp390.235.00 } \\
0\end{array}$ & $\begin{array}{l}\text { Rp350.500.00 } \\
0\end{array}$ \\
\hline $\begin{array}{l}\text { Total biaya } \\
\text { pencegahan }\end{array}$ & $\begin{array}{l}\text { Rp300.000.00 } \\
\text { O }\end{array}$ & $\begin{array}{l}\text { Rp325.500.00 } \\
\text { 0 }\end{array}$ & $\begin{array}{l}\text { Rp347.977.00 } \\
\text { 0 }\end{array}$ & $\begin{array}{l}\text { Rp390.235.0 } \\
\text { 00 }\end{array}$ & $\begin{array}{l}\text { Rp350.500.0 } \\
00\end{array}$ \\
\hline \multicolumn{6}{|c|}{$\begin{array}{l}\text { Biaya } \\
\text { Penilaian : }\end{array}$} \\
\hline $\begin{array}{l}\text { Biaya } \\
\text { Tenaga } \\
\text { Kerja } \\
\text { Pengawas/M } \\
\text { andor }\end{array}$ & Rp 53.232.000 & Rp 53.850.000 & $\begin{array}{l}\mathrm{Rp} \\
39.250 .000\end{array}$ & $\begin{array}{l}\text { Rp } \\
40.425 .000\end{array}$ & $\begin{array}{l}\mathrm{Rp} \\
57.867 .000\end{array}$ \\
\hline $\begin{array}{l}\text { Total biaya } \\
\text { penilaian }\end{array}$ & $\begin{array}{l}\text { Rp } \\
\text { 53.232.000 }\end{array}$ & Rp 53.850.000 & $\begin{array}{l}\text { Rp } \\
39.250 .000\end{array}$ & $\begin{array}{l}\text { Rp } \\
\text { 40.425.000 }\end{array}$ & $\begin{array}{l}\text { Rp } \\
\mathbf{5 7 . 8 6 7 . 0 0 0}\end{array}$ \\
\hline $\begin{array}{l}\text { Total Biaya } \\
\text { Kualitas }\end{array}$ & $\begin{array}{l}\text { Rp353.232.00 } \\
0\end{array}$ & $\begin{array}{l}\text { Rp379.350.00 } \\
0\end{array}$ & $\begin{array}{l}\text { Rp387.227.00 } \\
\text { 0 }\end{array}$ & $\begin{array}{l}\text { Rp430.660.0 } \\
\text { O0 }\end{array}$ & $\begin{array}{l}\text { Rp } \\
\text { 408.367.00 } \\
\end{array}$ \\
\hline
\end{tabular}

Tabel 2. Perbandingan Item Kualitas Terhadap Total Penjualan (\%)

\begin{tabular}{|c|c|c|c|c|c|}
\hline Item & 2014 & 2015 & 2016 & 2017 & 2018 \\
\hline \multicolumn{6}{|l|}{ Biaya Pencegahan : } \\
\hline Biaya pemeliharaan & 3,49 & 3,51 & 3,49 & 3,85 & 3,40 \\
\hline Total biaya pencegahan & 3,49 & 3,51 & 3,49 & 3,85 & 3,40 \\
\hline \multicolumn{6}{|l|}{ Biaya Penilaian : } \\
\hline $\begin{array}{l}\text { Biaya tenaga kerja } \\
\text { pengawas/mandor }\end{array}$ & 0,62 & 0,58 & 0,39 & 0,40 & 0,56 \\
\hline Total biaya penilaian & 0,62 & $\mathbf{0 , 5 8}$ & $\mathbf{0 , 3 9}$ & $\mathbf{0 , 4 0}$ & 0,56 \\
\hline Total Biaya Kualitas & 4,11 & 4,09 & 3,88 & 4,25 & 3,96 \\
\hline
\end{tabular}




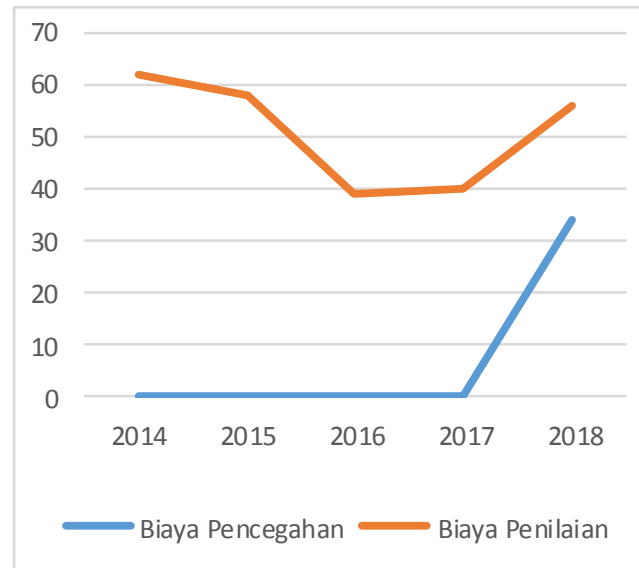

\section{Gambar 2. Persentase Biaya Kualitas Terhadap Total Penjualan}

Dari Tabel 2 dapat dilihat bahwa biaya kualitas mengalami pergerakan yang tidak stabil. Biaya pencegahan tahun 2015 naik sebesar $0,02 \%$ dari tahun 2014. Untuk tahun 2016 biaya pencegahan turun sebesar $-0.02 \%$ dari tahun sebelumnya. Biaya pencegahan 2017 mengalami kenaikan sebesar 0,36\% dari tahun 2016. Dan untuk tahun 2018 biaya pencegahan mengalami penurunan sebesar $-0,45 \%$ dari tahun sebelumnya.

Sedangkan untuk biaya penilaian tahun 2015 turun sebesar sebesar -0,04\% dari tahun 2014. Untuk tahun 2016 biaya penilaian turun sebesar $-0,19 \%$ dari tahun sebelumnya. Biaya penilaian 2017 mengalami kenaikan sebesar 0,01\% dari tahun 2016. Dan untuk tahun 2018 biaya pencegahan mengalami kenaikan sebesar $0,16 \%$ dari tahun sebelumnya.

Total biaya kualitas selama lima periode mengalami pergerakan yang tidak stabil. Pada tahun 2015 mengalami penurunan sebesar -0,02\% dari tahun 2014 . Untuk tahun 2016 mengalami penurunan juga sebesar $-0,21 \%$ dari tahun sebelumnya. Pada tahun 2017 mengalami kenaikan sebesar 0,37\% dari tahun 2016. Dan pada tahun 2018 mengalami penurunan sebesar $-0,29 \%$. 
Tabel 3. Taksiran Biaya Kualitas Tahun 2018

\begin{tabular}{|c|c|c|c|c|c|}
\hline Item & Total & $\begin{array}{c}\text { Biaya } \\
\text { Variab } \\
\text { el }\end{array}$ & $\begin{array}{l}\text { Biaya } \\
\text { Tetap }\end{array}$ & $\begin{array}{c}\text { Biaya } \\
\text { Semivariab } \\
\text { el }\end{array}$ & $\begin{array}{c}\text { Pers } \\
\text { enta } \\
\text { se } \\
(\%)\end{array}$ \\
\hline \multicolumn{6}{|l|}{ Biaya Pencegahan : } \\
\hline $\begin{array}{l}\text { Biaya } \\
\text { Pemeliharaan }\end{array}$ & Rp175.250.000 & & & $\begin{array}{l}\operatorname{Rp} \\
175.250 .000\end{array}$ & 1,70 \\
\hline $\begin{array}{l}\text { Total biaya } \\
\text { pencegahan }\end{array}$ & $\begin{array}{l}\text { Rp175.250.00 } \\
\text { 0 }\end{array}$ & & & $\begin{array}{l}\text { Rp } \\
175.250 .000\end{array}$ & 1,70 \\
\hline \multicolumn{6}{|l|}{ Biaya Penilaian : } \\
\hline $\begin{array}{l}\text { Biaya Tenaga } \\
\text { Kerja } \\
\text { Pengawas/Mandor }\end{array}$ & Rp 57.867.000 & & $\begin{array}{l}\text { Rp57.867. } \\
000\end{array}$ & & 0,56 \\
\hline $\begin{array}{l}\text { Total biaya } \\
\text { penilaian }\end{array}$ & Rp 57.867.000 & & $\begin{array}{l}\text { Rp57.867. } \\
000\end{array}$ & & $\mathbf{0 , 5 6}$ \\
\hline $\begin{array}{l}\text { Total } \quad \text { Biaya } \\
\text { Kualitas }\end{array}$ & $\begin{array}{l}\text { Rp233.117.00 } \\
\text { 0 }\end{array}$ & & $\begin{array}{l}\text { Rp57.867. } \\
000\end{array}$ & $\begin{array}{l}\text { Rp } \\
175.250 .000\end{array}$ & 2,26 \\
\hline Total Penjualan & $\begin{array}{l}\text { Rp10.317.120. } \\
000\end{array}$ & & & & \\
\hline
\end{tabular}

(Sumber : Data Olahan dari CV. Ulung Baureno Bojonegoro, 2019)

Tabel 4. Perbandingan Persentase Aktual Dan Taksiran Biaya Kualitas Tahun 2018

\begin{tabular}{lll}
\hline Item & Aktual & Taksiran \\
\hline Biaya Pencegahan : & & \\
Biaya pemeliharaan & 3,40 & 1,70 \\
Total biaya pencegahan & $\mathbf{3 , 4 0}$ & $\mathbf{1 , 7 0}$ \\
Biaya Penilaian : & & \\
Biaya tenaga kerja pengawas/mandor & 0,56 & 0,56 \\
Total biaya penilaian & $\mathbf{0 , 5 6}$ & $\mathbf{0 , 5 6}$ \\
Total Biaya Kualitas & $\mathbf{3 , 9 6}$ & $\mathbf{2 , 2 6}$ \\
\hline
\end{tabular}

(Sumber : Data Olahan dari CV. Ulung Baureno Bojonegoro, 2019)

Berdasarkan Tabel 4 diatas dapat disimpulkan bahwa dengan taksiran yang dilakukan oleh peneliti, perusahaan dapat menekan biaya kualitas sebesar 1,70\% yang awalnya $3,96 \%$ menjadi $2,26 \%$ yang menandakan bahwa persentase taksiran biaya kualitas dibawah standar $2,5 \%$ dari total penjualan. Untuk biaya pencegahan 
mengalami penurunan dari biaya kualitas aktual sebesar $1,70 \%$ dan biaya penilaian masih berada di persentase yang sama yakni sebesar $0,56 \%$.

\section{PEMBAHASAN}

Biaya kualitas merupakan bagian dari biaya produksi. Sehingga kenaikan atau penurunan biaya kualitas berakibat pada kenaikan ataupun penurunan biaya produksi.

Tabel 5. Penurunan dan Kenaikan Biaya Produksi

\begin{tabular}{|c|c|c|c|}
\hline Jenis Biaya & 2018 (Rp) & Taksiran & $\begin{array}{ll}\text { Penurunan } & (-) \\
\text { Kenaikan } \\
\text { Biaya }\end{array}$ \\
\hline $\begin{array}{l}\text { Biaya } \\
\text { Pencegahan }\end{array}$ & Rp 350.500 .000 & 175.250 .000 & (-) Rp 175.250 .000 \\
\hline $\begin{array}{l}\text { Biaya } \\
\text { Penilaian }\end{array}$ & $\mathrm{Rp} \quad 57.867 .000$ & 57.867 .000 & - \\
\hline $\begin{array}{l}\text { Jumlah Biaya } \\
\text { Kualitas }\end{array}$ & Rp 408.367 .000 & 233.117 .000 & (-) Rp 175.250.000 \\
\hline $\begin{array}{l}\text { Biaya } \\
\text { Produksi }\end{array}$ & Rp11.893.154.600 & Rp 11.717.904.600 & (-) Rp 175.250.000 \\
\hline
\end{tabular}

(Sumber : Data Olahan dari CV. Ulung Baureno Bojonegoro, 2019)

Berdasarkan Tabel 5 biaya kualitas mengalami penurunan sebesar Rp 175.250.000. Penurunan biaya ini merupakan bagian dari biaya produksi. Jadi, biaya kualitas dapat membuat biaya produksi lebih efisien sebesar Rp 175.250.000. Efisiensi biaya tersebut disajikan dalam tabel dibawah ini.

Tabel 6. Persentase Efisiensi Biaya

\begin{tabular}{|c|c|c|c|c|}
\hline Jenis Biaya & 2018 (Rp) & Taksiran & Efisiensi & $\begin{array}{l}\text { Persenta } \\
\text { se }(\%)\end{array}$ \\
\hline $\begin{array}{l}\text { Biaya } \\
\text { Kualitas }\end{array}$ & Rp 408.367.000 & $\begin{array}{l}\mathrm{Rp} \\
233.117 .000\end{array}$ & $\begin{array}{l}\operatorname{Rp} \\
175.250 .000\end{array}$ & 1,70 \\
\hline $\begin{array}{l}\text { Total } \\
\text { Penjualan }\end{array}$ & Rp10.317.120.000 & & & \\
\hline
\end{tabular}

(Sumber : Data Olahan dari CV. Ulung Baureno Bojonegoro, 2019)

Hasil uji ini sama dengan hasil penelitian yang dilakukan Dwi Nugraha Pratiwi Bawon Jullie, dkk. (2013), Nilisye Debora Ratag, dkk. (2013), dan Marchel Saputra Marlando Tulende dan Ventje Ilat (2014) yang meneliti mengenai biaya kualitas, menggunakan metode deskriptif dengan pendekatan kuantitatif dimana biaya kualitas dapat mempengaruhi biaya yang ada termasuk pada efisiensi produksi perusahaan. Dengan demikian penerapan biaya kualitas yang menggunakan metode deskriptif dengan pendekatan kuantitatif pada penelitian ini telah tepat dan sesuai dengan penelitian sebelumnya. 


\section{KESIMPULAN DAN SARAN \\ Simpulan}

Berdasarkan hasil penelitian dan pembahasan yang dilaksanakan oleh peneliti di CV. Ulung Baureno Bojonegoro tentang penerapan biaya kualitas untuk meningkatkan efisiensi biaya produksi selama lima periode dapat dambil kesimpulan sebagai berikut :

CV. Ulung Baureno Bojonegoro belum menerapkan dan mengukur biaya kualitasnya, sehingga perusahaan belum mengetahui biaya-biaya apa saja yang termasuk ke dalam biaya kualitas dalam proses produksi. Dengan menetapkan biaya kualitas perusahaan dapat mengetahui jenis dan proporsi biaya kualitas yang terjadi dalam kegiatan peningkatan kualitasnya, dan perusahaan dapat menentukan tindakan yang harus dilakukan untuk mencapai biaya kualitas dan produksi lebih efisien.

\section{Saran}

Berdasarkan hasil penelitian yang dilakukan, peneliti mengajukan saran penelitian sebagai berikut:

CV. Ulung Baureno Bojonegoro agar melakukan penerapan biaya kualitas sebaiknya dilakukan secara teratur dan periodik oleh perusahaan agar perkembangan yang terjadi pada biaya kualitas dapat segera diketahui dan dievaluasi. Hal ini perlu dilakukan agar perusahaan dapat mengambil keputusan untuk memperbaiki perencanaan dan pengendalian kualitas serta perusahaan dapat mengambil tindakan yang akan menurunkan biaya pencegahan yang terlalu besar tanpa mengurani kualitas produk yang dihasilkan. Yang diharapkan penurunan biaya yang akan terjadi lebih besar dari kenaikan biaya. 


\section{DAFTAR PUSTAKA}

Andi Ibrahim, dkk. (2018), Metodologi Penelitian, Cetakan Pertama, Makassar: Gunadarma Ilmu.

Cecily A. Raiborn and Michael R. Kinney (2016), Akuntansi Biaya Dasar Dan Perkembangan, Cetakan Pertama, Edisi Tujuh, Jakarta: Salemba Empat.

Dwi Nugraha Pratiwi Bawon, dkk. (2013), Penerapan Biaya Kualitas Untuk Meningkatkan Efisiensi Biaya Produksi Pada PT. PERTANI (PERSERO) Cabang Sulawesi Utara, Jurnal Riset Akuntansi Going concern, 8(3), 4857.

Grahita Chandrarin (2017), Metode Riset Akuntansi Pendekatan Kuantitatif, Jakarta: Salemba Empat.

Hansen Don. R and Mowen M. Maryanne (2012), Akuntansi Manajerial, Cetakan Pertama, Edisi Delapan, Jakarta: Salemba Empat.

Kiki Adelina Wahyuningtias (2013), Pengaruh Biaya Kualitas Terhadap Produk Rusak Pada CV. Ake Abadi, Jurnal EMBA, Vol. 1, No. 3 Edisi Juni 2013: 321-330.

Marchel Saputra Marlando Tulende dan Ventje Ilat (2014), Penerapan Biaya Kualitas Untuk Meningkatkan Efisiensi Produksi Pada UD. Sinar Sakti Manado, Jurnal EMBA, 2(2), 1712-1722.

Moh. Zainal Abidin, Tri Lestari, dan Juliani Pudjowati (2015), Analisis Biaya Pelaporan Dan Penggunaan Biaya Kualitas Sebagai Upaya Meminimalkan Terjadinya Prdouk Cacat Pada UD. Jagir Jaya di Surabaya, Jurnal Akuntansi UBHARA, Edisi 2015:235-250.

Mustika Rahmi, Eka Rosalina, dan Irda Rosita (2015), Penerapan Biaya Kualitas Dalam Meningkatkan Efisiensi Biaya Produksi Pada Catering ABC, Jurnal Akuntansi \& Manajemen, Vol. 10, No. 1 Edisi Juni 2015: 25-35.

Nilisye Debora Ratag, David Paul Elia Saerang, dan Lidia Mawakere (2013), Penerapan Biaya Kualitas Dalam Meningkatkan Efisiensi Produksi Pada PT. Tropica Cocoprima, Jurnal Riset Akuntansi Going concern, Vol. 8, No. 3 Edisi September 2013:58-68.

Suharsimi Arikunto (2014), Prosedur Penelitian : Suatu Pendekatan Praktik, Cetakan Lima Belas, Jakarta: Rineka Cipta.

William K. Carter (2009), Akuntansi Biaya, Cetakan Pertama, Edisi Empat Belas, Jakarta: Salemba Empat.

Bisman (Bisnis dan Manajemen): The Journal Of Business and Management 